\title{
Charakterystyka mineralogiczno-geochemiczna mineralizacji kasyterytowo-siarczkowej w historycznych sztolniach św. Jana i św. Leopolda w paśmie łupkowym Starej Kamienicy (Sudety Zachodnie)
}

\author{
Rafał Małek ${ }^{1}$, Stanisław Z. Mikulski ${ }^{1}$, Andrzej Chmielewski ${ }^{1}$
}

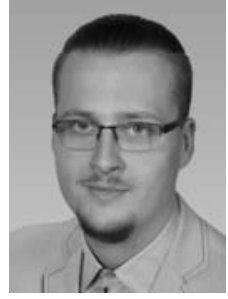

R. Małek

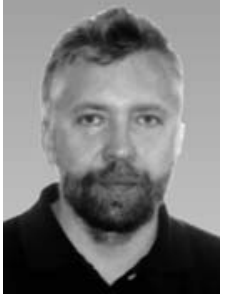

S.Z. Mikulski

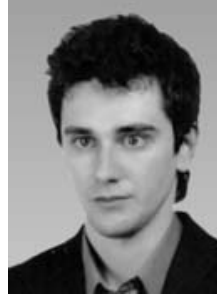

A. Chmielewski

The geochemical-mineralogical characteristic of cassiterite-sulphide mineralization in the historic Saint John and Saint Leopold shafts in the Stara Kamienica shist belt (Western Sudetes). Prz. Geol., 67: 914-924; doi: $10.7306 / 2019.50$

A b s tra ct. Drifts historical of St. John and St. Leopold historical tin mine in Krobica, located within the Stara Kamienica shist belt of the Sudetes Mountains were a subject of intermittent exploitation from the $16^{\text {th }}$ through the $20^{\text {th }}$ centuries. Initial $X$-ray examinations inside historical ore excavations using a field portable $\mathrm{pXRF}$ spectrometer and laboratory geochemical analysis by WD-XRF, ISP-MS and GF-AAS methods were carried out. These studies showed elevated concentrations of a range of elements (Bi, $\mathrm{Hf}$, In, $\mathrm{Pd}, \mathrm{Pt}, \mathrm{Sc}, \mathrm{Sb}, \mathrm{W}, \mathrm{As}, \mathrm{Ag}, \mathrm{Cd}, \mathrm{Re}, \mathrm{Zn}, \mathrm{Pb}$ and some REE), which are recognized as critical for the European Union economy. The reflected-light microscopic examination has confirmed the occurrence of a cassiterite-sulfide mineralization that was exploited in historical times. A number of analyses was performed using an electron microprobe (EMPA). This allowed us to recognize a series of minerals (mainly ore minerals) as carriers of the above-mentioned elements. The following ore minerals were identified in the samples examined: chalcopyrite, sphalerite, pyrite, arsenopyrite, pyrrhotite, gersdorffite, as well as mimetite and xenotime.

Keywords: cassiterite, sulfides, strategic elements, touristic shafts, Krobica, Western Sudetes

Przedmiotem kompleksowych prac geochemiczno-mineralogicznych były udostępnione turystycznie połączone stare wyrobiska kopalni św. Jana i sztolni św. Leopolda w Krobicy w paśmie Starej Kamienicy w Sudetach Zachodnich. Zakres prac obejmował ocenę zawartości pierwiastków chemicznych przy użyciu przenośnego spektrometru (pXRF Delta firmy Olympus), punktowe opróbowanie wyrobisk oraz jakościowo-ilościowe badania geochemiczne (ICP-MS, XRF, GF-AAS), mikroskopowe i w mikroobszarze (Cameca SX-100). Wszystkie prace zostały wykonane w ramach projektu PSG w Państwowym Instytucie Geologicznym - Państwowym Instytucie Badawczym (PIG-PIB), sfinansowanego przez Narodowy Fundusz Ochrony Środowiska i Gospodarki Wodnej (NFOŚiGW) (Mikulski i in., 2018).

Kopalnictwo cyny w rejonie Krobicy i Gierczyna jest datowane na początek XVI w., a w źródłach historycznych pochodzących z 1580 r. podawano, że produkcja cyny wynosiła wówczas ok. 70 t tego metalu rocznie (Dziekoński, 1972). Gwałtowne załamanie robót górniczych nastąpiło u schyłku XVI w., co było przypuszczalnie wynikiem wyczerpania się bogatszych i łatwiej dostępnych partii złóż. Nowy etap w rozwoju kopalnictwa w tym rejonie nastąpił po 1648 r., czyli po zakończeniu wojny trzydziestoletniej. Rozpoczęto wtedy prace w kopalniach St. Johannes (św. Jan) oraz ReicherTrost, w których wyrobiska osiagnęły głębokość odpowiednio 28 i 40 m (ibidem). Zalanie kopalni ReicherTrost w 1668 r. przyczyniło się do ponownego zaniechania robót górniczych w tym rejonie. W okresie od 1755 do 1770 r. miejscowi gwarkowie i górnicy prowadzili wydobycie rud cyny w kopalni św. Jana, a w okresie 1790 1792 również podjęto wydobycie rudy kobaltu ze sztolni św. Leopolda zlokalizowanej w bezpośrednim sąsiedztwie.
Wydobyto wówczas 39,55 t rudy kobaltowej (Moczydłowska, Zagożdżon, 2013). Ponowne zainteresowanie wydobyciem rud w kopalni św. Jana i sztolni św. Leopolda miało miejsce w latach 1810-1816, a następnie dopiero w roku 1938 (Dziekoński, 1972). W okresie powojennym w rejonie Krobica-Gierczyn-Przecznica prowadzono intensywne prace poszukiwawcze zakończone udokumentowaniem kilku złóż kasyterytowych cyny, takich jak: złoże Krobica i Krobica II (Janik i in., 1984), Krobica Zachód-Czerniawa (Michniewicz, Sroga, 1987) oraz Gierczyn (Neumann, Olszewski, 1991). Obowiązujące od 2002 r. kryteria bilansowości dla złóż cyny zmieniają charakter zasobów wszystkich udokumentowanych dotychczas złóż na pozabilansowe. Zasoby pozabilansowe dla złoża Gierczyn wynoszą 2890000 trudy, a dla złoża Krobica - 2603000 t, prz średniej ważonej wartości Sn w rudzie od 0,23 do $0,87 \%$ (Malon i in., 2018).

\section{ZARYS BUDOWY GEOLOGICZNEJ OBSZARU BADAŃ}

Pasmo łupkowe Starej Kamienicy, w obrębie którego zlokalizowane są wyrobiska św. Jana i św. Leopolda, stanowi część metamorfiku karkonosko-izerskiego (północnej okrywy granitu karkonowskiego) w Sudetach Zachodnich (ryc. 1) (Smulikowski, 1972; Mochnacka i in., 2015). W jego skład wchodzą dwa kompleksy skalne. Pierwszy z nich jest reprezentowany przez gnejsy, granitognejsy i granity przedwaryscyjskie, a drugi - to zróżnicowane litologicznie łupki kwarcowo-chlorytowo-łyszczykowe różniące się zmiennym udziałem poszczególnych składników mineralnych oraz zawartością cyny. Kompleksy łupków w obrębie skał gnejsowo-granitowych tworzą pięć wydłużonych równo-

\footnotetext{
${ }^{1}$ Państwowy Instytut Geologiczny - Państwowy Instytut Badawczy, Rakowiecka 4, 00-975 Warszawa; rafal.malek@pgi.gov.pl; stanislaw.mikulski@pgi.gov.pl; andrzej.chmielewski@pgi.gov.pl
} 


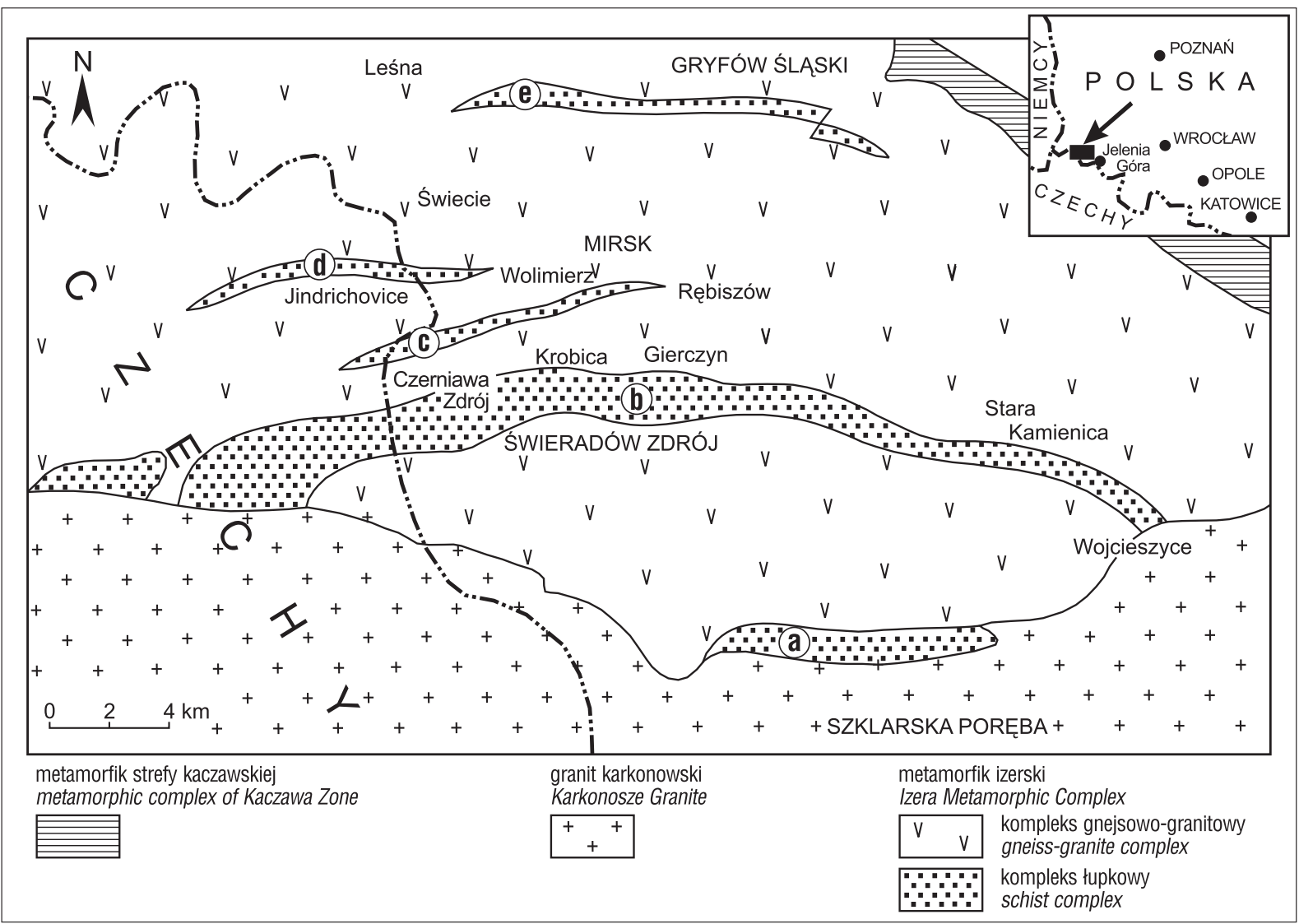

Ryc. 1. Pasma łupkowe w strukturze metamorfiku izerskiego; a - pasmo Szklarskiej Poręby, b - pasmo Starej Kamienicy, c - pasmo Mirska, d - pasmo Jindřichovic, e - pasmo Złotnik Lubańskich (wg Michniewicza i in., 2006)

Fig. 1. The schist belts within the eastern part of the Izera Metamorphic Complex; a - Szklarska Poręba Schist Belt, b - Stara Kamienica Schist Belt, c - Mirsk Schist Belt, d - Jindřrichovice Schist Belt, e - Złotniki Lubańskie Schist Belt (acc. to., Michniewicz et al., 2006)

leżnikowo pasm, wśród których największe jest pasmo Starej Kamienicy (ryc. 1).

Łupki łyszczykowe, w których występuje mineralizacja kasyterytowo-siarczkowa, są skałami drobnoziarnistymi o jasnoszarej lub srebrzystoszarej barwie (często z zielonkawym odcieniem, ryc. 3A) i strukturze granolepidoblastycznej, z wyraźnie widoczną foliacją i laminacją. Głównymi składnikami mineralnymi łupków jest kwarc i muskowit oraz występujące w nieco mniejszych ilościach chloryt i biotyt (Wiszniewska, 1984; Michniewicz i in., 2006). Niekiedy w pewnych partiach łupków do głównych minerałów skałotwórczych można zaliczyć również granaty i albit. Łupki cynonośne mają miaższość od 50 do $180 \mathrm{~m}$ i zalegają pomiędzy pakietami łupków płonnych, od których różnią się większą ilością biotytu, granatów, chlorytu oraz wyższą zawartością żelaza (Szałamacha, Szałamacha, 1974; Michniewicz i in., 2006, wraz z literatura). W całym pakiecie łupkowym występują soczewki kwarcowe (często zbudinowane, ryc. 3C) oraz fałdki i żyłki kwarcowe sporadycznie zawierające blaszki chlorytu oraz ziarna kalcytu czy fluorytu (Michniewicz i in., 2006).

Głównym minerałem kruszcowym występującym w izerskich rudach cyny jest kasyteryt $\left(\mathrm{SnO}_{2}\right)$, dodatkowo w nielicznych przypadkach stwierdzono również obecność stanninu $\left(\mathrm{Cu}_{2} \mathrm{FeSnS}_{4}\right)$ (Karwowski, Włodyka, 1981). Nośnikiem niewielkich ilości cyny są również minerały skałotwórcze: biotyty (zawierające do 260 ppm Sn) i chloryty (do 140 ppm Sn) (Kucha, Mochnacka, 1998). Kasyteryt występuje w łupkach w postaci drobnoziarnistych wydzieleń lub $\mathrm{w}$ formie pojedynczych rozporoszonych ziaren tworzących groniaste i/lub sznureczkowe zgrupowania w asocjacji z kwarcem i chlorytem, rzadziej z siarczkami metali, muskowitem oraz biotytem. Był również opisywany w formie wrostków w większości minerałów skałotwórczych łupków (również w granatach) (Wiszniewska, 1984; Bobiński, 1991).

Siarczki metali pochodzenia hydrotermalnego obecne w strefach zmineralizowanych sa zazwyczaj łatwo identyfikowalne makroskopowo, jednak nie wykazują istotnych związków z mineralizacją cynową - stanowią odrębną asocjację mineralną (Mikulski i in., 2018). Występują w laminach lub w większych skupieniach kwarcu, są to przede wszystkim: pirotyn, chalkopiryt, arsenopiryt, sfaleryt, galena i piryt oraz występujący rzadziej bizmutynit. Łącznie zostało rozpoznanych ok. 50 minerałów kruszcowych współwystępujących wraz z mineralizacją kasyterytowa, przypisanych formacji kwarcowo-chlorytowo-siarczkowych złóż cyny (Wiszniewska, 1984). Minerały kobaltu takie jak kobaltyn, saffloryt czy kobaltonośny löllingit $\mathrm{w}$ większych ilościach występowały w rudach z historycznej kopalni Anna-Maria, natomiast poza tym rejonem ww. minerały występują tylko śladowo, a kobalt jako domieszka izomorficzna - w arsenopirycie i löllingicie (Piestrzyński i in., 1992; Piestrzyński, Mochnacka, 2003).

\section{ZAKRES PRAC ORAZ METODYKA}

Prace prospekcyjne zostały przeprowadzone w udostępnionych turystycznie sztolniach po dawnym kopalnictwie rud cyny i kobaltu w Krobicy (ryc. 2). 


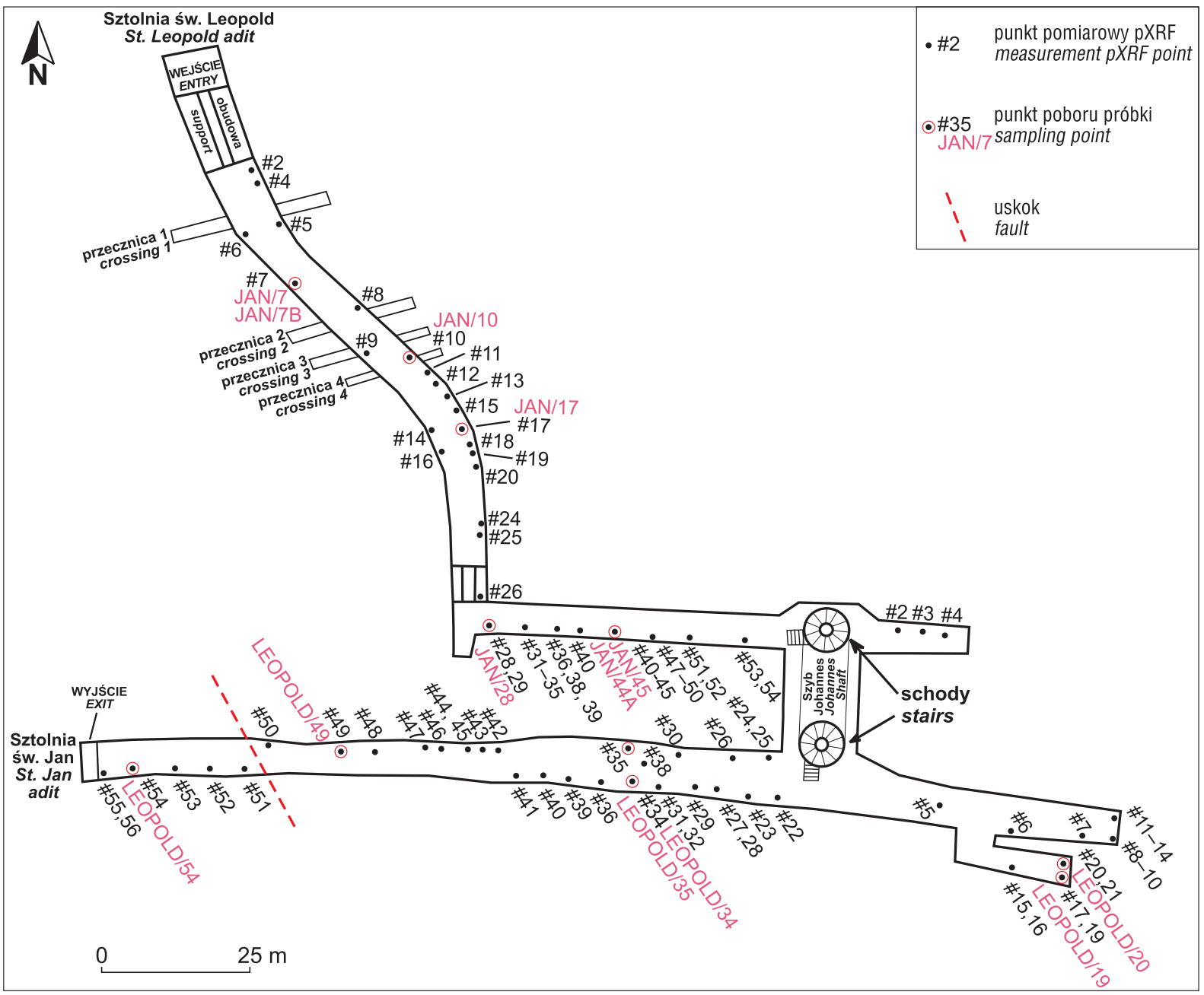

Ryc. 2. Schemat wyrobisk górniczych św. Jana i św. Leopolda z lokalizacją punktów pomiarów przy użyciu pXRF i pobrania próbek

Fig. 2. Schematic plans of the Saint Jan and the Saint Leopold mine workings with pXRF measurements and sampling points

Położenie i przebieg wyrobisk

Badany kompleks składa się z dwóch sztolni położonych na różnych rzędnych. Wylot starszej sztolni św. Jana znajduje się na wysokości 441,6 m n.p.m. Oba wyrobiska są ze sobą połączone szybem, a ich łączna długość wynosi ok. $350 \mathrm{~m}-\mathrm{z}$ czego udostępniona trasa turystyczna liczy ok. $300 \mathrm{~m}$. Wyrobiska przyjmują generalny przebieg WNW-ESE. Sztolnia św. Leopolda w przybliżeniu przebiega $\mathrm{W}$ poprzek dominującego kierunku strukturalnego foliacji i złupkowacenia skał, którego bieg ma wartość $75-100^{\circ}$, a upad 40-70 ${ }^{\circ}$ zazwyczaj w kierunku N (Szałamacha, 1967; Michniewicz i in., 2002). Natomiast wyrobisko kopalni św. Jana przebiega zgodnie z kierunkiem strukturalnym łupków (ryc. 2). Trasa turystyczna rozpoczyna się u wlotu sztolni św. Leopolda, która przyjmuje kierunek SE. Po kilkudziesięciu metrach obudowy drewnianej zaznaczają się 4 przecznice - podsadzone, dawne wyrobiska eksploatacyjne (odchodzących ku E lub E i W) - całkowita długość szybu to ok. $150 \mathrm{~m}$. Kilka metrów przed przodkiem, w kierunku wschodnim odchodzi chodnik eksploatacyjny o długości ok. 70 m, który w dalszej części stanowi podszybie szybu św. Jana, łączący oba wyrobiska w jeden szlak turystyczny (Moczydłowska, Zagożdżon, 2013). Wlot sztolni św. Jana znajduje się ok. 15 metrów od koryta Krobickiego Potoku (Zagożdżon, Zagożdżon, 2012), wyrobisko w miarę konsekwentnie przyjmuje kierunek wschodni.
Po ok. 85 m od wylotu znajduje się szyb św. Jana ze schodami, a za nim jeszcze kilkunastometrowy odcinek wyrobiska z przodkiem, nad którym dodatkowo występuje kilkumetrowej głębokości nisza, powstała w wyniku eksploatacji nadpoziomowej z pozostawieniem około metrowej grubości półki skalnej.

\section{Pomiary pXRF}

Pomiary przenośnym spektrometrem pXRF Delta firmy Olympus wykonano w ociosach i stropach wyrobisk korytarzowych, jak również w pozostałościach dawnych przodków eksploatacyjnych (ryc. 2, 3). Miejsca pomiarów wybierano zarówno pod względem widocznych makroskopowo śladów historycznej eksploatacji, dostrzegalnych przejawów mineralizacji siarczkowej, jak i zaznaczających się występowaniem wtórnej mineralizacji wietrzeniowej (ryc. 3B). Zdecydowana większość pomiarów została wykonana w obrębie udostępnionej trasy turystycznej, część $\mathrm{z}$ nich przeprowadzono również $\mathrm{w}$ obrębie wyrobisk trudno dostępnych, nieprzeznaczonych do zwiedzania. Wykonano w sumie ok. 100 punktowych pomiarów pierwiastków chemicznych. Oznaczone zostały (z różnym poziomem błędu pomiarowego) następujące pierwiastki chemiczne: Ti, V, $\mathrm{Cr}, \mathrm{Mn}, \mathrm{Fe}, \mathrm{Co}, \mathrm{Ni}, \mathrm{Cu}, \mathrm{Zn}, \mathrm{Rb}, \mathrm{Sr}, \mathrm{Y}, \mathrm{Zr}, \mathrm{Nb}, \mathrm{Mo}, \mathrm{Ag}, \mathrm{Sn}$, Ta, W, Au, Pb, Bi, Th, U, Ba, La, Ce, P, S, K. 

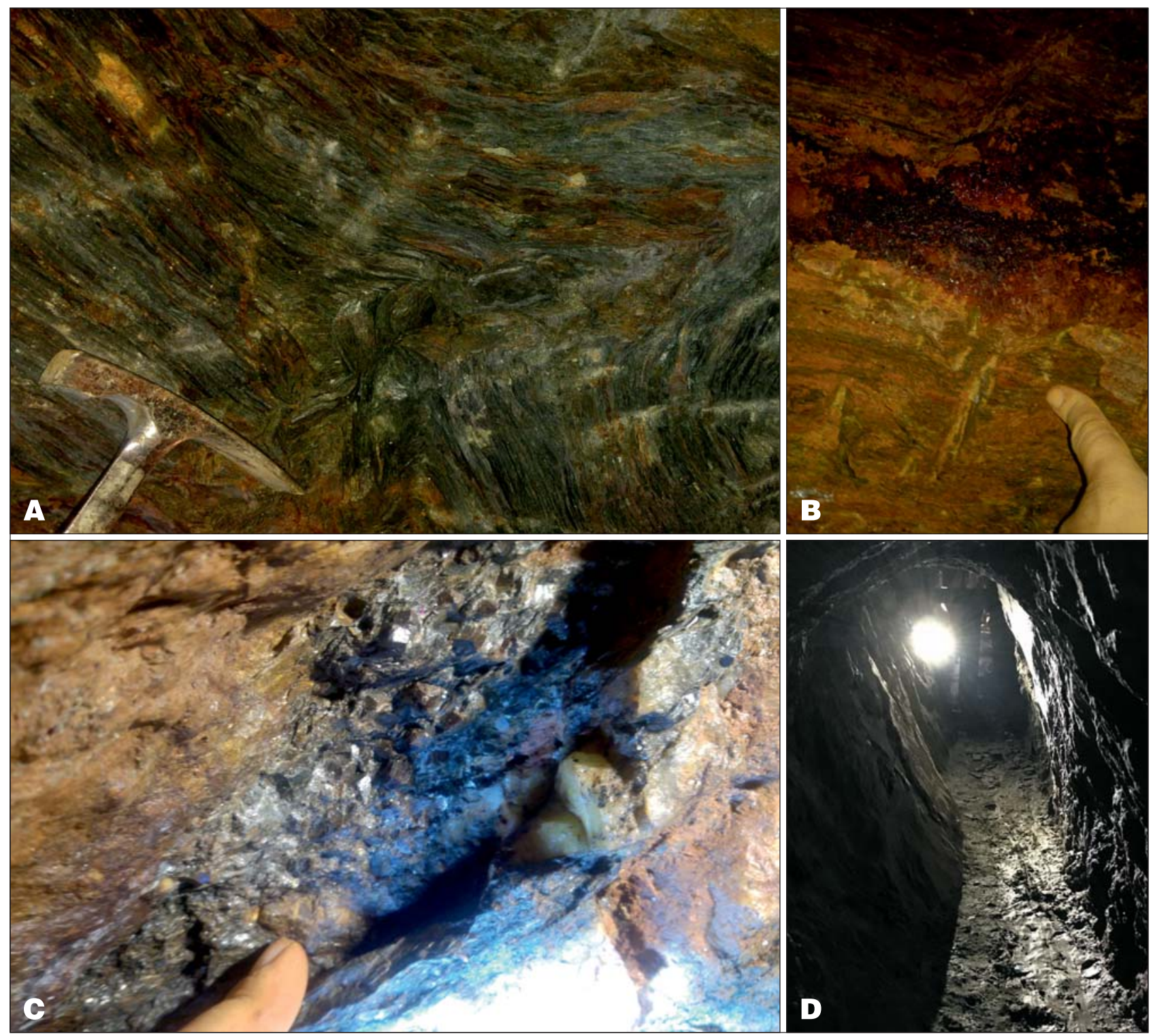

Ryc. 3. A - świeży, niezwietrzały ocios w sztolni św. Leopolda, B - wietrzeniowe wykwity żelaziste w stropie wyrobiska, C - szczelina z widocznym nagromadzeniem granatów oraz budiny kwarcowe w łupkach, D - wyrobisko korytarzowe w kopalni św. Jana

Fig. 3. A - fresh and unweathered side wall in the St. Leopold mine, B - ferruginous efflorescences on the mine roof, $\mathbf{C}-$ schist crack with a visible garnet accumulation and quartz boudins, $\mathbf{D}-$ the St. Jan mine gallery

W najciekawszych pod względem okruszcowania miejscach pobrano próbki okruchów skalnych (ryc. 2), z których wykonano preparaty mikroskopowe przeznaczone do obserwacji zarówno w świetle przechodzącym, jak i odbitym. Badania mineralogiczno-petrograficzne oraz dokumentację fotograficzną obrazu mikroskopowego przeprowadzono na mikroskopie NIKON ECLIPSE LV100 POL. Ponadto na próbce JAN 10 wykonano badania ilościowo-jakościowe na wybranych minerałach kruszcowych za pomocą mikrosondy elektronowej typu CAMECA SX-100.

\section{WYNIKI BADAŃ}

\section{Pomiary przenośnym spektrometrem pXRF}

Pomiary wykonane $\mathrm{w}$ wyrobiskach sztolni św. Jana i św. Leopolda w Krobicy przy użyciu przenośnego spektrometru pXRF wykazały znacznie podwyższoną zawartość niektórych pierwiastków (tab. 1). Wanad występuje w zakresie $24-3458 \mathrm{ppm}$ (śr. arytm. $=259 \mathrm{ppm}$ ), kobalt natomiast pojawił się w wyniku pojedynczej analizy i wykazał zawartość 792 ppm. Innymi pierwiastkami o podwyższonej koncentracji zmierzonej przy użyciu pXRF (dla $n=110$ ) są miedź (16-6562 ppm, śr. arytm. $=303$ ppm), cynk (37$1468 \mathrm{ppm}$, śr. arytm. $=390 \mathrm{ppm})$, ołów $(10-22830 \mathrm{ppm}$, śr. arytm. $=528 \mathrm{ppm})$, wolfram $(52-159 \mathrm{ppm}$, śr. arytm. $=$ $=105 \mathrm{ppm})$ oraz lantan $(73-454 \mathrm{ppm}$, śr. arytm. $=132 \mathrm{ppm})$ i cer $(84-769$ ppm, śr. arytm. $=206$ ppm). Porównanie wartości średnich wszystkich pierwiastków, których występowanie określiły pomiary przenośnym spektrometrem, przedstawiono na rycinie 4 .

\section{Laboratoryjne badania geochemiczne}

Przedmiotem badań geochemicznych było 13 próbek ze sztolni św. Jana i św. Leopolda w Krobicy. Lokalizację punktów poboru próbek w sztolniach zaznaczono na rycinie 2. Analizy chemiczne WD-XRF, ICP-MS, GF AAS wykonano w laboratorium PIG-PIB. Podstawowe parametry statystyczne oznaczeń chemicznych pierwiastków zostały przedstawione $\mathrm{w}$ tabeli 2 . 


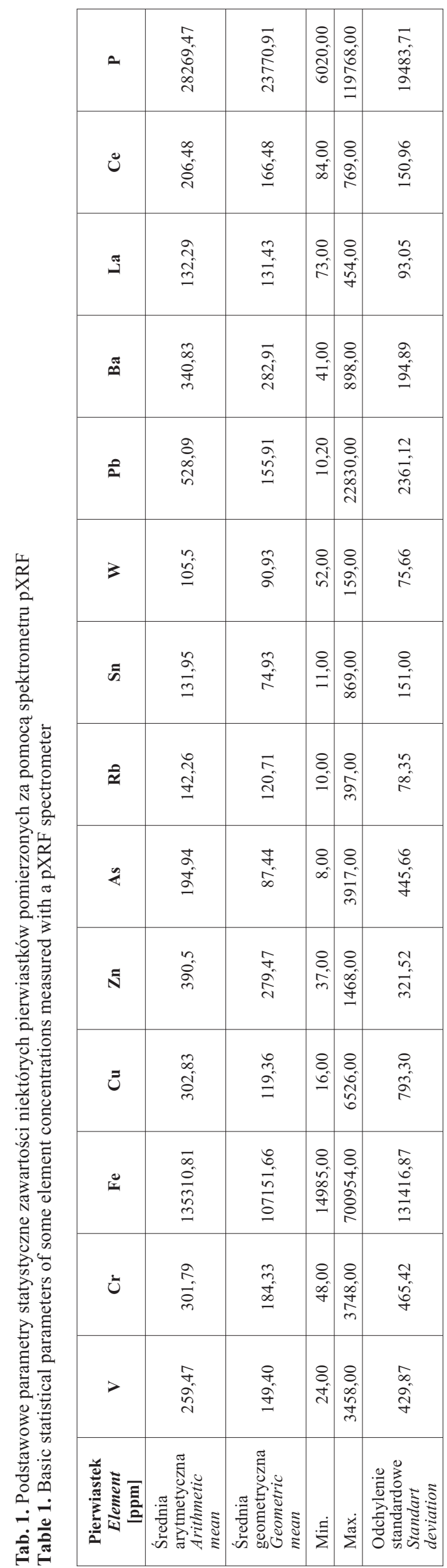

Na histogramie przedstawiającym porównanie średnich arytmetycznych wybranych pierwiastków w odniesieniu do ich średnich zawartości (klarku) w skorupie ziemskiej widoczne jest silne wzbogacenie w ren (ponad $900 \times)$, cynę i arsen $(>100 \times)$ oraz w kadm, ołów, bizmut, skand, platynę i pallad (10-60×), a także niewielkie wzbogacenie (5-10x) w srebro, cynk oraz antymon (ryc. 5).

Zbadane za pomocą metodyki WD-XRF próbki z przejawami mineralizacji kasyterytowej zawierają cynę w zakresie od $<2$ do $2890 \mathrm{ppm}$. Cyna wykazuje słabą korelację z indem (współczynnik korelacji $r=0,52$ dla $n=13$ ) oraz bardzo słabą z miedzią $(r=0,42)$. Średnia arytmetyczna zawartość Sn wynosi 367,3 ppm, przy czym w 30\% populacji jej koncentracje były >200 ppm. Próbka o najwyższej koncentracji cyny z mineralizacją kasyterytowo-siarczkową (LEOPOLD/54, ryc. 2) wykazuje również podwyższoną zawartość Cu (240 ppm), Zn (224 ppm) i Pb (333 ppm). Rozkład zawartości renu w próbach jest symetryczny, w zakresie od 0,23 do 0,57 ppm (śr. arytm. $=0,37 \mathrm{ppm}$ ). Wykazuje on silną korelację z ołowiem $(r=0,71)$, a średnią z hafnem $(r=0,59)$. Wzbogacenie $\mathrm{W}$ arsen (maksymalnie do $0,19 \%$ As; śred. art. $=272,3$ ppm) jest związane głównie z obecnością arsenopirytu. Rozkład populacji w zakresie koncentracji arsenu jest asymetryczny jednomodalny, ok. $30 \%$ wykazuje $>160 \mathrm{ppm}$ As. Arsen charakteryzuje się bardzo silną korelację z Zn $(r=0,93)$ oraz silną korelacją z Pd $(r=0,89)$, Co $(r=0,77)$ i Ge $(r=0,76)$. Średnia arytmetyczna zawartość kadmu wynosi 12,6 ppm (przy zakresie 1,5-51 ppm). Kadm wykazuje bardzo silną korelację z As $(r=0,95)$ oraz silną korelację z Co, Ge i Pd $(r=$ ok. 0,8$)$. Ołów występuje w zakresie od $1,5 \mathrm{ppm}$ do ok. $0,71 \% \mathrm{~Pb}$. Na histogramie częstości ok. $62 \%$ próbek wykazuje $>100$ ppm. Średnia arytmetyczna jest wysoka - wynosi $665,4 \mathrm{ppm}$. Ołów wykazuje bardzo silną korelację z hafnem $(r=0,95)$, silną z uranem i renem $(r=0,71)$ oraz słabszą $\mathrm{z}$ kobaltem $(r=0,56)$ i palladem $(r=0,51)$. Srebro jest obecne w zakresie $<0,15 \mathrm{ppm}(n=5)$ do $1,4 \mathrm{ppm}$. Średnia geometryczna dla $\mathrm{Ag}$ jest niska $=0,52 \mathrm{ppm}$. Zawartość cynku w próbkach wynosi 167-3692 ppm. Srednia geometryczna $=$ ok. $445 \mathrm{ppm}$. Cynk wykazuje bardzo silną korelację z As $(r=$ $=0,93) \mathrm{i} \mathrm{Cd}(r=0,88) \mathrm{i} \mathrm{Br}(r=0,79)$ oraz słabą z $\mathrm{Co}(r=0,40)$ i Ge $(r=0,56)$. Z kolei Cu wykazuje słabą korelację z Sb, Sn i W $(r=0,53)$, a średnia geometryczna zawartość mie$\mathrm{dzi}=111 \mathrm{ppm}$ (zakres 41-415 ppm).

Wśród zbadanych pierwiastków wystęujących w próbkach pobranych z historycznych sztolni św. Jana i św. Leopolda znajdują się również takie, które znalazły się w opublikowanym w 2017 r. przez Komisję Europejską wykazie surowców krytycznych dla Unii Europejskiej (COM, 2017). Należy tu przede wszystkim podkreślić występowanie koncentracji bizmutu, indu, palladu, platyny, skandu, kobaltu oraz niektórych pierwiastków ziem rzadkich. Na podstawie oznaczeń wykonanych metodyką WD-XRF wykazano, że zmienność bizmutu mieści się w zakresie od $<0,05$ do $25 \mathrm{ppm}$, a średnia arytmetyczna wynosi 4,5 ppm i jest ponad 3-krotnie niższa od średniej stwierdzonej w próbkach z obszaru pasma Starej Kamienicy (Mikulski i in., 2018). Większość próbek zawiera $>1 \mathrm{ppm} \mathrm{Bi}(n=8)$. Bizmut wykazuje silną korelację z Au $(r=0,85)$ oraz słabą korelację $\mathrm{z}$ galem $(r=0,68)$, torem $(r=0,59)$, antymonem $(\mathrm{r}=0,55) \mathrm{i}$ indem $(r=0,50)$. Inne pierwiastki krytyczne, takie jak skand, platyna oraz pallad wykazują ponad dwudziestokrotne wzbogacenie w stosunku do ich klarków w skorupie ziemskiej. Platyna wykazuje interesujące koncentracje wśród pierwiastków szlachetnych 


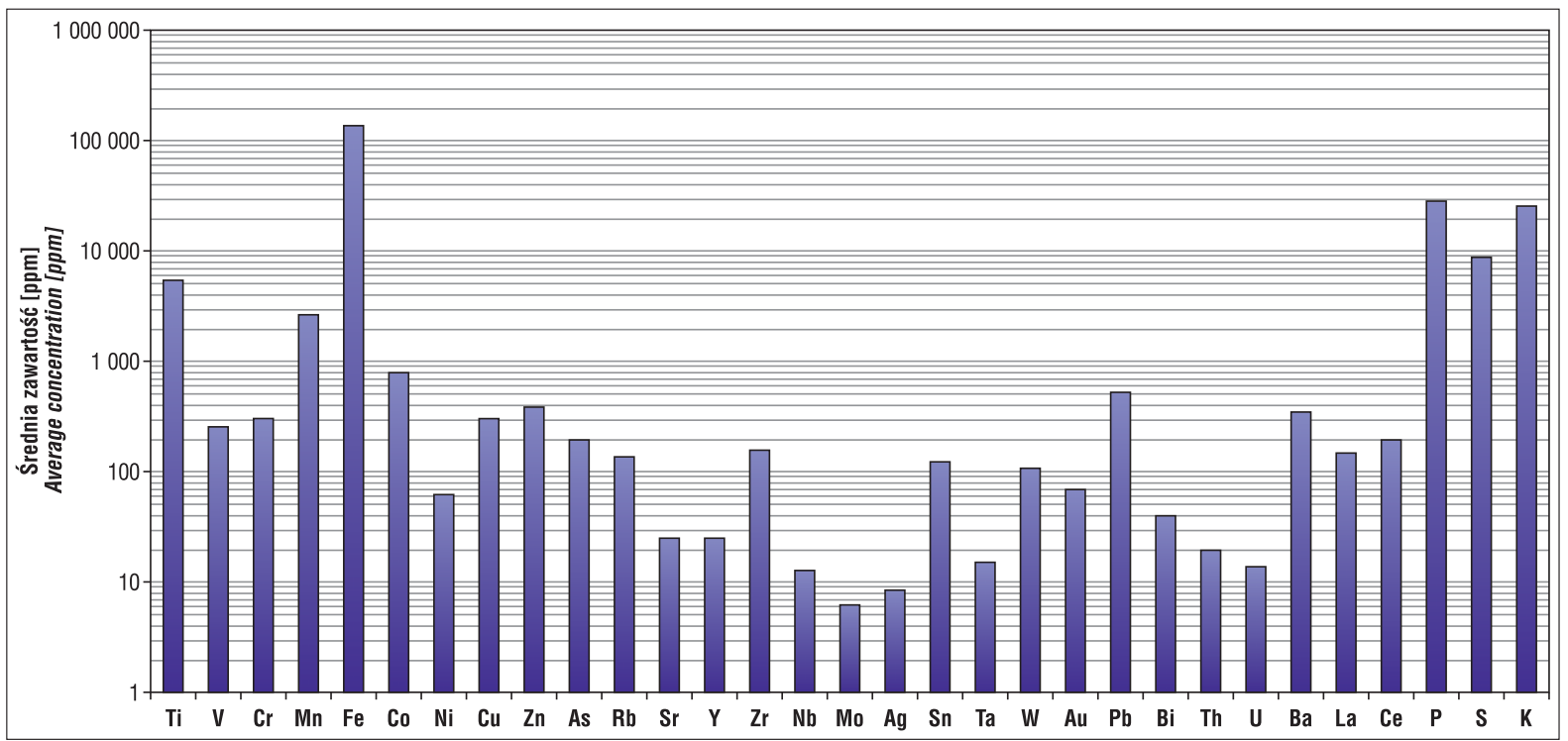

Ryc. 4. Wykres średnich zawartości pierwiastków pomierzonych za pomocą spektrometru pXRF (średnia arytmetyczna dla $n=93$ pomiarów)

Fig. 4. Histogram of the average element concentrations measured with pXRF spectrometer (arithmetic average for $n=93$ measurements

stwierdzonych zarówno w próbkach z obszaru sztolni w Krobicy, jak i w całym cynonośnym paśmie Starej Kamienicy, w zakresie od 15 do 99 ppb. Na histogramie częstości zawartości platyny rozkład jest jednomodalny symetryczny. Największą zawartość Pt zanotowano w pięciu próbkach w przedziale od 50 do $100 \mathrm{ppb}$. Średnia geometryczna wynosi ok. 58,7 ppb ( $n=13$ próbek). Platyna wykazuje słabą korelację z germanem $(r=0,68)$, uranem $(r=0,57)$, kobaltem i arsenem $(r=0,53)$ oraz bardzo słabą korelację $\mathrm{z}$ Hf, Pd, Re i Zn $(r=0,48-0,40)$. Pallad w zakresie od 2,5 do $45 \mathrm{ppb}$ występuje w 70\% liczby próbek. Średnia geometryczna wynosi ok. 7,4 ppb, wykazuje on silną korelację z As $(r=0,89), \operatorname{Co}(r=0,81)$, germanem $(r=0,78)$ i cynkiem $(r=0,74)$, a słabą z Hf, Pb, U i Pt $(r==$ ok. 0,48$)$. Skand jest obecny w próbkach w przedziale od ok. $<0,3$ do 15,3 ppm. Średnia geometryczna dla wystąpień skandu $=$ ok. 5 ppm, a średnia arytmetyczna - 9,59 ppm, wykazuje on bardzo silną korelację z REE, Th, Hf, Zr, Ga, Nb i Zn oraz słabą korelację m.in. z Sn $(r=0,68)$ oraz In $(r=0,64)$. Ważnym pierwiastkiem krytycznym występującym w podwyższonych koncentracjach w próbkach z obszaru złóż cyny jest również ind, którego zawartość na terenie złożowym wynosiła maks. do ok. 7,4 ppm (Mikulski i in., 2018). Dla próbek pochodzących ze sztolni średnia geometryczna $=$ ok. 0,17 ppm (zakres $<0,03-0,60 \mathrm{ppm})$. Ind wykazuje silną korelację z Ga, La i W $(r=0,74)$ oraz słabą z Th $(r=0,64)$, Sn, Bi, $\mathrm{Au}, \mathrm{Ni}$ i Sb $(r=0,52-0,50)$. Kobalt jest obecnie jednym z najważniejszych pierwiastków krytycznych. Występuje w siarczkach, głównie w kobaltynie oraz w pirotynie i pirycie, które towarzyszą mineralizacji kasyterytowej. Zakres koncentracji kobaltu mieści się w niewielkim przedziale od 10 do $66 \mathrm{ppm}$. Średnia geometryczna zawartość Co w próbkach wynosi 19,7 ppm. Kobalt wykazuje silną korelację z Ge, Pd i As ( $r=0,88-0,77)$ oraz słabą z Hf, Pb, Pt i Zn. Pozostałe pierwiastki krytyczne, takie jak wanad, gal, german, wolfram, hafn, tal czy niob, występują w bardzo niskich koncentracjach (tab. 1). Koncentracje złota są również śladowe ( $<1$ do $18 \mathrm{ppb})$. Wykresy współzależności niektórych par pierwiastków przedstawiono na rycinie 6 .
Wśród pierwiastków ziem rzadkich najwyższą średnią geometryczną obliczono dla ceru (analizy ICP-MS), która wynosi 46,1 ppm, a zakres zmienności od 1,9 do 97,5 ppm. Suma REE to 5,9-260,0 ppm, a średnia geometryczna - ok. 103,5 ppm $(n=13$; mediana $=158,8$ ppm; średnia arytmetyczna = ok. 136,2 ppm). Stosunek lekkich REE (od La do Gd) do pierwiastków zaliczanych do ciężkich HREE (od $\mathrm{Tb}-\mathrm{Lu}+\mathrm{Y}$ ) mieści się zakresie od ok. 2 do 6,9. Podstawowe parametry statystyczne zawartość REE w badanych próbkach zaprezentowano w tabeli 3 .

$\mathrm{Na}$ wykresach zostały przedstawione koncentracje REE (dla $n=13$ próbek) znormalizowane do zawartości chondrytu wg McDonougha, Suna (1995) oraz w stosunku do łupków europejskich wg Bau i in. (2018) (ryc. 7).

Na wykresie znormalizowanym do chondrytu widoczne jest wzbogacenie w LREE w stosunku do MREE i HREE oraz niewielka ujemna anomalia Eu, która tylko dla dwóch próbek zaznacza się wyraźnie. Zwartości LREE są zdecydowanie wzbogacone w stosunku do chondrytu (ok. 40-250×). Przy normalizacji wyników do łupków europejskich zauważalne jest nieznaczne zubożenie zawartości REE w próbkach ze sztolni. Na obu wykresach są widoczne dwie próbki (Leopold/19 i Leopold/20), które mają wyraźnie niższe zawartości REE.

\section{Badania mikroskopowe i w mikroobszarze}

Obserwacje makroskopowe i mikroskopowe badania preparatów wykazały, że pobrane próbki łupków łyszczykowych (cynonośnych) to skały drobnoziarniste, barwy jasnoszarej o zielonkawym odcieniu, laminowane z widoczną, wyraźną foliacją. Głównymi minerałami skałotwórczymi są: muskowit, kwarc, biotyt i chloryt, podrzędnie występują również skalenie, granaty i dysten oraz minerały akcesoryczne, takie jak apatyt, monacyt oraz cyrkon. Ponadto w skałach łupkowych została stwierdzona uboga żyłkowo-impregnacyjna mineralizacja siarczkowa i tlenkowa. Jest ona reprezentowana głównie przez: pirotyn, piryt, chalkopiryt, sfaleryt, arsenopiryt, kasyteryt, ilmenit, kowelin, hematyt, goethyt i rutyl. W świetle odbitym kasy- 
Tab. 2. Parametry statystyczne zawartości pierwiastków na podstawie badań WD-XRF oraz ICP-MS i GF ASS próbek z historycznej kopalni cyny w Krobicy w paśmie łupkowym Starej Kamienicy $(n=13$ próbek)

Table. 2. Statistical parameters of the element concentrations based on results derived from WD-XRF, ICP-MS and GF-AAS measurements in the Krobica historical tin mine located in the Stara Kamienica schist belt ( $n=13$ samples)

\begin{tabular}{|c|c|c|c|c|c|c|}
\hline \multirow{2}{*}{$\begin{array}{c}\text { Pierwiastek } \\
\text { Element } \\
\text { [ppm] }\end{array}$} & \multicolumn{6}{|c|}{$n=13$} \\
\hline & $\begin{array}{l}\text { Średnia artm. } \\
\text { Arithmetic mean }\end{array}$ & $\begin{array}{l}\text { Średnia geometr. } \\
\text { Geometric mean }\end{array}$ & $\begin{array}{c}\text { Mediana } \\
\text { Median }\end{array}$ & $\begin{array}{l}\text { Minimum } \\
\text { Minimum }\end{array}$ & $\begin{array}{c}\text { Maksimum } \\
\text { Maximum }\end{array}$ & $\begin{array}{l}\text { Odchylenie std. } \\
\text { Standard deviation }\end{array}$ \\
\hline As & 272,38 & 65,87 & 36,00 & 7,00 & 1891,00 & 535,69 \\
\hline $\mathrm{Ba}$ & 193,08 & 90,32 & 237,00 & 5,00 & 418,00 & 137,92 \\
\hline Co & 25,46 & 19,72 & 16,00 & 10,00 & 66,00 & 20,80 \\
\hline $\mathrm{Cr}$ & 43,15 & 28,49 & 47,00 & 1,50 & 75,00 & 23,12 \\
\hline $\mathrm{Cu}$ & 137,92 & 111,21 & 117,00 & 41,00 & 415,00 & 101,53 \\
\hline $\mathrm{Ga}$ & 14,58 & 10,04 & 17,00 & 1,50 & 29,00 & 8,78 \\
\hline $\mathrm{Hf}$ & 5,31 & 3,80 & 4,00 & 1,50 & 24,00 & 5,87 \\
\hline $\mathrm{Nb}$ & 10,38 & 9,49 & 13,00 & 4,00 & 15,00 & 3,91 \\
\hline $\mathrm{Ni}$ & 30,23 & 25,59 & 27,00 & 4,00 & 55,00 & 15,06 \\
\hline $\mathrm{Pb}$ & 665,42 & 102,62 & 111,00 & 1,50 & 7089,00 & 1933,05 \\
\hline $\mathrm{Rb}$ & 90,08 & 61,83 & 84,00 & 8,00 & 184,00 & 58,39 \\
\hline $\mathrm{Sr}$ & 37,31 & 33,58 & 35,00 & 16,00 & 91,00 & 19,23 \\
\hline $\mathrm{Th}$ & 8,35 & 6,56 & 9,00 & 1,50 & 14,00 & 4,29 \\
\hline $\mathrm{U}$ & 3,62 & 3,31 & 4,00 & 1,00 & 7,00 & 1,45 \\
\hline $\mathrm{V}$ & 62,12 & 35,21 & 77,00 & 2,50 & 114,00 & 37,73 \\
\hline $\mathrm{Zn}$ & 656,08 & 445,00 & 399,00 & 167,00 & 3692,00 & 924,16 \\
\hline $\mathrm{Zr}$ & 91,00 & 55,99 & 111,00 & 1,00 & 157,00 & 52,03 \\
\hline $\mathrm{Br}$ & 3,96 & 3,26 & 3,00 & 0,50 & 11,00 & 2,67 \\
\hline $\mathrm{Cd}$ & 12,65 & 8,32 & 8,00 & 1,50 & 51,00 & 13,66 \\
\hline $\mathrm{Sn}$ & 367,31 & 53,41 & 96,00 & 1,00 & 2890,00 & 782,60 \\
\hline $\mathrm{Ge}$ & 0,22 & 0,20 & 0,20 & 0,10 & 0,40 & 0,11 \\
\hline $\mathrm{Ag}$ & 0,72 & 0,52 & 0,90 & 0,15 & 1,40 & 0,48 \\
\hline In & 0,26 & 0,17 & 0,25 & 0,03 & 0,60 & 0,19 \\
\hline $\mathrm{Sb}$ & 1,08 & 0,96 & 1,10 & 0,25 & 1,90 & 0,49 \\
\hline $\mathrm{Ta}$ & 0,56 & 0,31 & 0,55 & 0,03 & 1,23 & 0,39 \\
\hline W & 3,30 & 1,71 & 3,20 & 0,05 & 7,40 & 2,32 \\
\hline $\mathrm{Re}$ & 0,37 & 0,36 & 0,35 & 0,23 & 0,57 & 0,09 \\
\hline $\mathrm{Tl}$ & 0,45 & 0,29 & 0,33 & 0,03 & 1,00 & 0,32 \\
\hline $\mathrm{Bi}$ & 4,54 & 0,85 & 1,20 & 0,03 & 25,03 & 7,24 \\
\hline $\mathrm{Sc}$ & 9,59 & 4,98 & 11,50 & 0,25 & 15,30 & 5,63 \\
\hline Pd [ppb] & 12,23 & 7,35 & 5,00 & 2,50 & 45,00 & 13,69 \\
\hline $\mathrm{Pt}[\mathrm{ppb}]$ & 65,23 & 58,66 & 71,00 & 15,00 & 99,00 & 26,67 \\
\hline $\mathrm{Au}[\mathrm{ppb}]$ & 2,15 & 0,89 & 0,50 & 0,50 & 18,00 & 4,81 \\
\hline
\end{tabular}

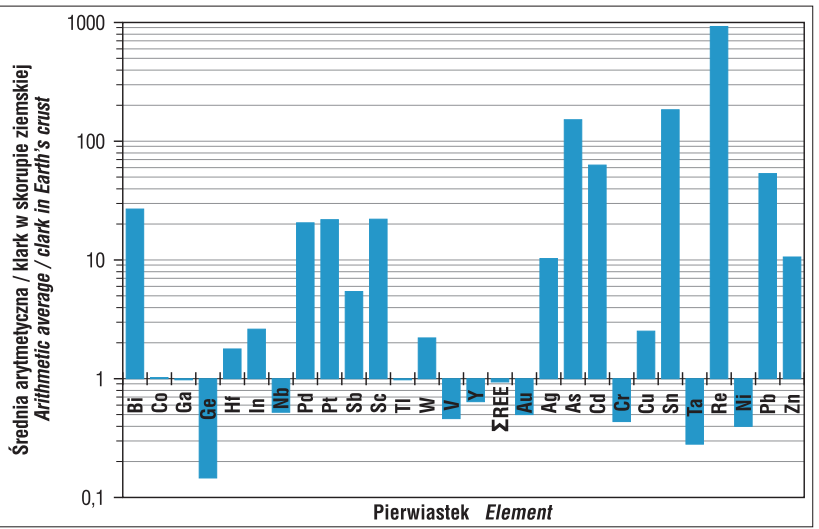

teryt charakteryzuje się szarą barwą, izotropią oraz słabymi refleksami wewnętrznymi (szaro-brązowe). Najczęściej kasyteryt występuje w asocjacji z kwarcem i chlorytem, rzadziej z siarczkami, muskowitem, chlorytoidem i biotytem (Michniewicz i in., 2006). Ponadto obserwowany jest jako wrostki praktycznie we wszystkich minerałach

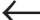

Ryc. 5. Histogram porównania średniej arytmetycznej zawartości pierwiastków w próbkach $(n=13)$ ze sztolni św. Jana i św. Leopolda w Krobicy w Sudetach w stosunku do ich średnich zawartości (klark) w skorupie ziemskiej (dane wg: Taylora, 1964; Barbalace'a, 2019)

Fig. 5. Comparison histogram of arithmetic means of element concentrations in samples $(n=13)$ from the St. Jan and St. Leopold adits relative to its average concentrations (clark) in the Earth's crust (data after: Taylor, 1964; Barbalace, 2019)

skałotwórczych łupków (Bobiński, 1991). Kasyteryt jest trudno rozpoznawalny makroskopowo ze względu na niewielkie rozmiary ziaren $(<0,4 \mathrm{~mm}$ średnicy) oraz swój szaro-brazowy kolor. W obrazie mikroskopowym został zaobserwowany w bardzo niewielkich ilościach w formie drobnych ziarenek (do $10 \mu \mathrm{m}$ średnicy), występujących w skupieniach groniastych głównie w obrębie lamin chlorytowych, ale także jako wrostki w kwarcu, muskowicie i sporadycznie w granatach. Impregnacje kaserytowe są zazwyczaj 

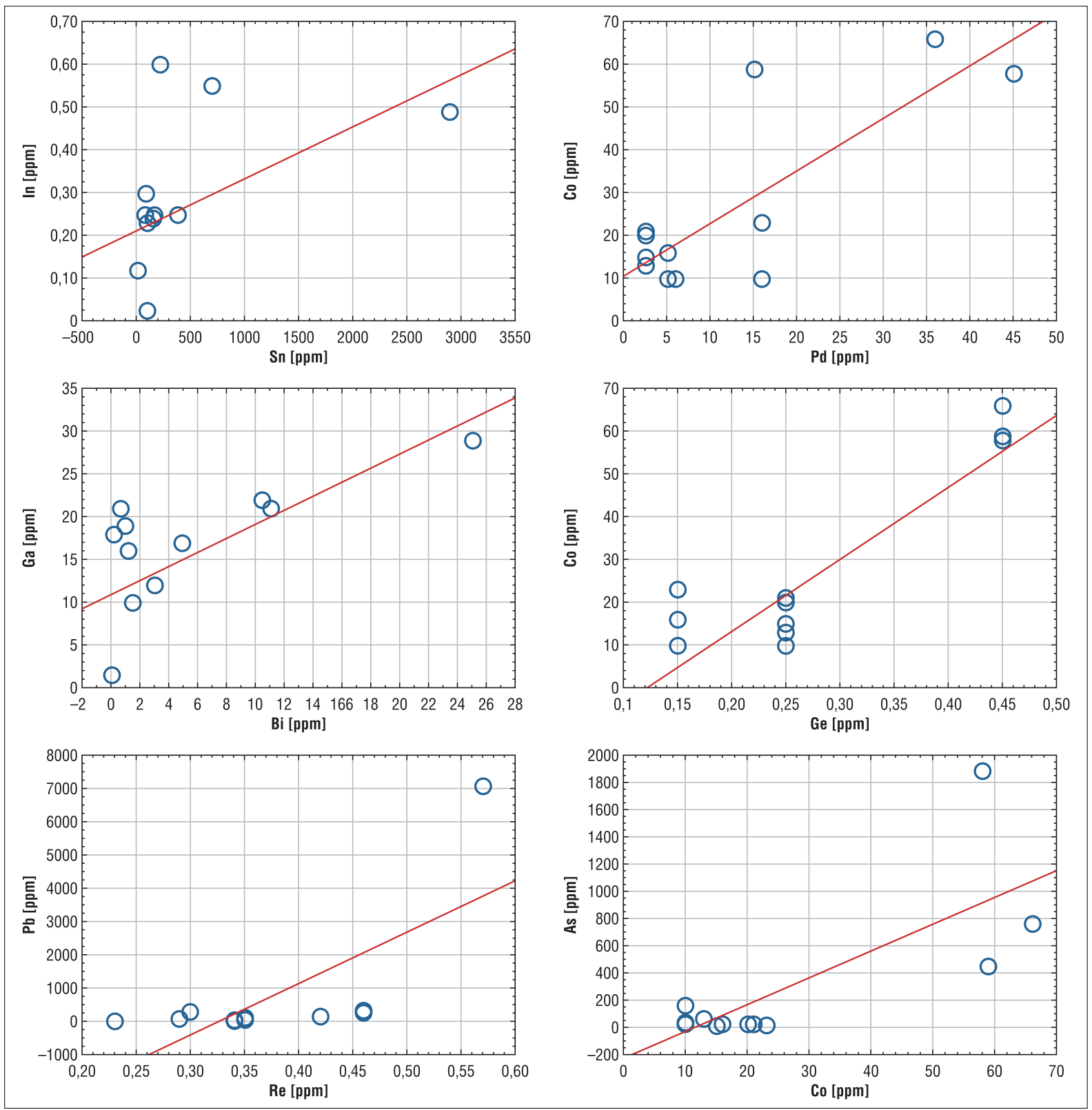

Ryc. 6. Wykres rozrzutu Sn do In, Pd do Co, Bi do Ga, Ge do Co, Re do Pb oraz Co do As w próbkach z historycznej kopalni cyny w Krobicy

Fig. 6. Bivariate diagrams of: $\mathrm{Sn}$ vs. In, $\mathrm{Pd}$ vs. $\mathrm{Co}$, Bi vs. Ga, Ge vs. $\mathrm{Co}$, Re vs. Pb and Co vs. As in samples from the Krobica historical tin mine

ułożone liniowo, zgodnie z kierunkiem foliacji łupków. Ponadto wszystkie wystapienia kasyterytu wykazują cechy zaangażowania tektonicznego (Siemiątkowski, 1991).

Pirotyn i chalkopiryt zdecydowanie dominują wśród siarczków. Przeważnie ich ksenomorficzne kryształy tworzą duże agregaty, również z innymi siarczkami (pirytem, sfalerytem i arsenopirytem), o rozmiarach do $0,5 \mathrm{~cm}$ (ryc. $8 \mathrm{~A}-$ patrz str. 852). Pirotyn zawiera wrostki innych minerałów (siarczków). Chalkopiryt zdecydowanie rzadziej niż pirotyn zawiera wrostki innych minerałów, natomiast sam nierzadko tworzy wrostki głównie w granatach (ryc. 8C patrz str. 852). Miejscami jest zastępowany przez kowelin (ryc. 8B - patrz str. 852). Piryt występuje rzadziej niż pirotyn i chalkopiryt, współtworzy z nimi agregaty siarczkowe, tworzy zrosty z pirotynem. Przejawia on postać kseromorficzną oraz sporadycznie hipautomorficzną. Ilmenit jest najpowszechniej występującym minerałem kruszcowym w ba- danych preparatach. Występuje zarówno jako impregnacja skały z niewielkimi kryształami o rozmiarach maksymalnie do 300-400 $\mu \mathrm{m}$ (ryc. 8D - patrz str. 852), jak i wspólnie z siarczkami tworzy agregaty krystaliczne (ryc. $8 \mathrm{~A}$ - patrz str. 852). Przyjmuje postać kseromorficzna, sporadycznie hipautomorficzną - wydłużone ziarna ułożone zgodnie z kierunkiem foliacji łupków. Arsenopiryt i sfaleryt występują sporadycznie, wraz $\mathrm{z}$ innymi siarczkami w postaci niewielkich agregatów (maks. do $100 \mu \mathrm{m}$ średnicy), które są ksenomorficzne. Magnetyt oraz rutyl podobnie jak ilmenit występuja jako drobna impregnacja skały, jednak zdecydowanie rzadziej. Goethyt został rozpoznany tylko w preparatach wykonanych z próbek pobranych z wietrzeniowych nacieków żelazistych (LEOPOLD 19, 20 i 49).

Badania próbki zawierającej mineralizację kruszcową (próbka JAN 10), przeprowadzone na mikrosondzie elektronowej (EMPA), pozwoliły na analizę składów chemicz- 
Tab. 3. Podstawowe parametry statystyczne zawartości REE oznaczone metodą ICP-MS

Table 3. Basic statistical parameters of REE concentrations measured with an ICP-MS method

\begin{tabular}{|l|c|c|c|c|}
\hline $\begin{array}{c}\text { Pierwiastek } \\
\text { Element } \\
\text { [ppm] }\end{array}$ & $\begin{array}{c}\text { Średnia } \\
\text { artm. } \\
\text { Arithmetic } \\
\text { mean }\end{array}$ & $\begin{array}{c}\text { Minimum } \\
\text { Minimum }\end{array}$ & $\begin{array}{c}\text { Maksimum } \\
\text { Maximum }\end{array}$ & $\begin{array}{c}\text { Odchylenie } \\
\text { standardowe } \\
\text { Standard } \\
\text { deviation }\end{array}$ \\
\hline $\mathrm{Sc}$ & 9,589 & 0,250 & 15,30 & 5,63 \\
\hline $\mathrm{Y}$ & 21,161 & 1,400 & 37,00 & 10,09 \\
\hline $\mathrm{La}$ & 22,954 & 1,200 & 51,90 & 12,58 \\
\hline $\mathrm{Ce}$ & 46,169 & 1,900 & 97,50 & 24,96 \\
\hline $\mathrm{Pr}$ & 5,527 & 0,250 & 12,20 & 3,10 \\
\hline $\mathrm{Nd}$ & 20,754 & 0,800 & 46,00 & 11,58 \\
\hline $\mathrm{Eu}$ & 1,232 & 0,025 & 3,05 & 0,79 \\
\hline $\mathrm{Sm}$ & 4,134 & 0,160 & 9,10 & 2,34 \\
\hline $\mathrm{Gd}$ & 3,928 & 0,180 & 7,57 & 2,03 \\
\hline $\mathrm{Tb}$ & 0,640 & 0,025 & 1,07 & 0,34 \\
\hline $\mathrm{Dy}$ & 4,009 & 0,150 & 7,12 & 2,12 \\
\hline $\mathrm{Ho}$ & 0,821 & 0,025 & 1,46 & 0,42 \\
\hline $\mathrm{Er}$ & 2,327 & 0,090 & 3,95 & 1,15 \\
\hline $\mathrm{Tm}$ & 0,319 & 0,025 & 0,53 & 0,16 \\
\hline $\mathrm{Yb}$ & 1,949 & 0,060 & 3,18 & 1,01 \\
\hline $\mathrm{Lu}$ & 0,274 & 0,025 & 0,46 & 0,14 \\
\hline $\mathrm{Th}$ & 7,084 & 0,060 & 11,33 & 4,23 \\
\hline
\end{tabular}
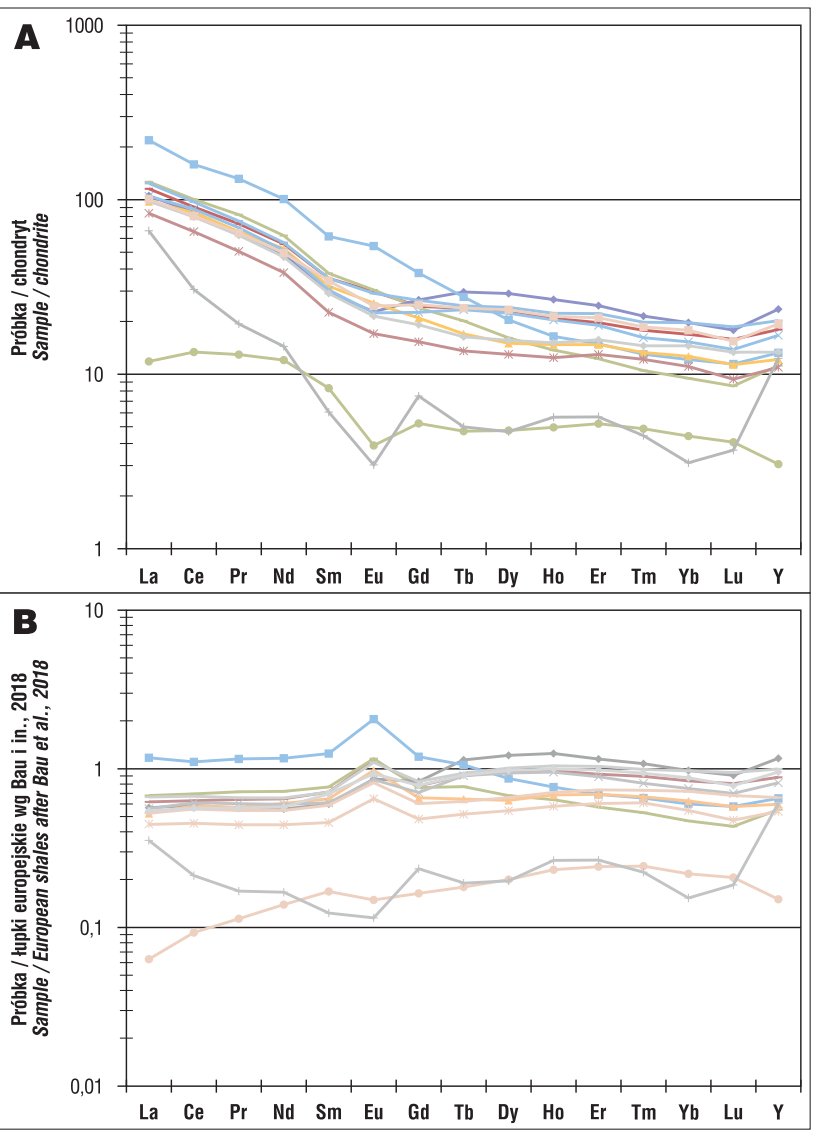

Ryc. 7. Wykresy koncentracji REE znormalizowanych do zawartości chondrytu wg McDonougha, Suna (1995) oraz w stosunku do łupków europejskich wg Bau i in., 2018

Fig. 7. Graphs of REE concentrations normalized to chondrite values (after McDonough, Sun, 1995) and European shales (after Bau et al., 2018) nych głównych minerałów kruszcowych oraz rozpoznanie kilku nowych faz mineralnych, które ze względu na niewielkie rozmiary były nierozpoznawalne przy użyciu mikroskopu optycznego. Wśród rozpoznanych na mikrosondzie minerałów są między innymi: gersdorffit [NiAsS], mime-

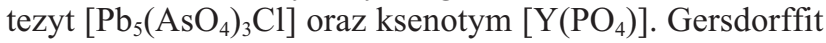
o rozmiarze ok. $50 \mu \mathrm{m}$ rozpoznano zaledwie w jednym miejscu szlifu, gdzie wraz z arsenopirytem tworzy niewielki agregat krystaliczny (ryc. $8 \mathrm{E}$ - patrz str. 852). Ksenotym w szlifie występuje dość licznie w formie bardzo niewielkich rozproszonych kryształów o rozmiarach najczęściej ok. $10 \mu \mathrm{m}$, zlokalizowanych w sąsiedztwie agregatów siarczkowych. Mimetezyt natomiast w zdecydowanej większości zaobserwowanych przypadków tworzył wtórne obwódki wokół minerałów kruszcowych - sfalerytu, pirytu i/lub chalkopirytu (ryc. 8F - patrz str. 852) lub występował fragmentarycznie także na ich krawędziach (ryc. 8E - patrz str. 852). Analizy jakościowo-ilościowe minerałów kruszcowych wykazały zawartość interesujących domieszek pierwiastków śladowych, takich jak kobalt, nikiel, selen, arsen, cynk oraz srebro (tab. 4). Chalkopiryt wykazał domieszki Zn (maks. 0,111\% wag.), sfaleryt zawierał interesujące domieszki $\mathrm{Ag}$ (maks. 0,289\% wag.) oraz Co (maks. 0,137\% wag.), piryt przejawiał zawartość Ni (maks. 0,661\% wag.). Z kolei w arsenopirycie stwierdzono domieszki niklu (maks. 0,809\% wag.) oraz niższe kobaltu (maks. 0,210\% wag.). Pojedynczy pomiar w gersdorfficie wykazał aż 11,219\% wag. domieszki Co oraz $0,416 \%$ wag. $\mathrm{Sb}$. Kobalt został rozpoznany również jako domieszka w mimetezycie (maks. 0,294\% wag.).

\section{PODSUMOWANIE WYNIKÓW I DYSKUSJA}

Rozpoznana mineralizacja kruszcowa w próbkach pobranych $z$ historycznych sztolni św. Jana i św. Leopolda jest reprezentowana głównie przez minerały tlenkowe i siarczki: kasyteryt, pirotyn, piryt, chalkopiryt, sfaleryt, arsenopiryt, ilmenit, kowelin, hematyt, goethyt i rutyl, a także gersdorffit, mimetezyt oraz ksenotym. Ilmenit i rutyl, występujące w rozproszeniu, są składnikami allogenicznymi metasedymentu, natomiast kasyteryt wraz z towarzyszącymi mu siarczkami mają charakter epigenetyczny i występują $\mathrm{w}$ formie żyłek oraz impregnacji przebiegających przeważnie zgodnie z filiacją łupków (Wiszniewska, 1984). Asocjacje mineralne, analogiczne do tych, które zostały rozpoznane w sztolniach św. Jana i św. Leopolda, opisywano w wielu wcześniejszych publikacjach dotyczących mineralizacji pasma łupkowego Starej Kamienicy, m.in. Kowalski i in. (1979), Wiszniewska (1983, 1984), Mochnacka (1986), Berendsen i in. (1987), Kucha i Mochnacka (1987, 1998), Kozłowski i in. (1988), Piestrzyński i in. (1992, 1990), Cook, Dudek (1994), Mochnacka i in. (2015) czy Mikulski i in. (2018). Geneza kompleksu łupkowego jest przedstawiana jako metamorfizm serii suprakrustalnej (Oberc, 1958; Kotowski, 1972; Szłamacha, Szałamacha, 1974; Oberc-Dziedzic, 1975). W świetle opublikowanych badań geologicznych można stwierdzić, że pasmo łupkowe Starej Kamienicy należy postrzegać jako spagową partię skał osłony intruzji gnejsów izerskich, a sama mineralizacja jest wynikiem działania hydrotermy związanej przestrzennie, czasowo i genetycznie $\mathrm{z}$ tą intruzją. Hydroterma ta, poprzez strukturę pułapkową w formie pierwotnego kompleksu osadowego zawartego pomiędzy ciałami intruzywnymi gnejsów, wnikała i przesycała roztworami systemy stref odprężeń 
Tab. 4. Maksymalne zawartości [\% wag.] domieszek pierwiastków chemicznych w minerałach kruszcowych zmierzone na mikrosondzie elektronowej (CAMECA SX-100)

Table 4. The maximum concentrations of selected elements [wt $\%$ ] in ore minerals measured with a electron microprobe (CAMECA SX-100)

\begin{tabular}{|l|c|c|c|c|c|c|c|c|c|c|c|}
\hline $\begin{array}{c}\text { Mineral } \\
\text { [\% wag.] } \\
\text { Mineral [wt\%] }\end{array}$ & Ag & Ni & Sb & Se & Pb & Zn & Au & As & Cu & Co & Fe \\
\hline $\begin{array}{l}\text { Mimetezyt } \\
\text { Mimetite }\end{array}$ & p.p.d. & 0,142 & 0,038 & p.p.d. & 70,561 & 0,196 & 0,060 & 13,587 & 0,452 & 0,294 & 1,346 \\
\hline $\begin{array}{l}\text { Chalkopiryt } \\
\text { Chalcopyrite }\end{array}$ & 0,036 & 0,034 & 0,048 & p.p.d. & 0,0240 & 0,111 & 0,043 & p.p.d. & 34,682 & 0,056 & 30,955 \\
\hline $\begin{array}{l}\text { Sfaleryt } \\
\text { Sphalerite }\end{array}$ & 0,289 & 0,048 & 0,027 & p.p.d. & 0,139 & 63,279 & 0,980 & 0,0270 & 0,178 & 0,137 & 6,240 \\
\hline $\begin{array}{l}\text { Piryt } \\
\text { Pyrite }\end{array}$ & 0,079 & 0,661 & 0,022 & p.p.d. & p.p.d. & 0,017 & 0,012 & 0,0400 & 0,0720 & 0,072 & 46,110 \\
\hline $\begin{array}{l}\text { Arsenopiryt } \\
\text { Arsenopyrite }\end{array}$ & 0,040 & 0,809 & 0,045 & 0,139 & 0,209 & 0,058 & 0,078 & 40,566 & 0,0790 & 0,210 & 36,263 \\
\hline $\begin{array}{l}\text { Gersdorffit } \\
\text { Gerdorffite }\end{array}$ & 0,044 & 26,600 & 0,416 & 0,075 & p.p.d. & 0,021 & 0,051 & 43,380 & 0,0210 & 11,219 & 8,020 \\
\hline
\end{tabular}

p.p.d. - poniżej poziomu detekcji / below detection level

syndeformacyjnych, powodując powstanie stref rudnych (Michniewicz i in., 2006). Według Wiszniewskiej (1984) geneza mineralizacji cynowo-siarczkowej łączy się z rozwojem procesów hydrotermalnych pozwiązanych z intruzją waryscyjskiego granitu karkonoskiego. Liczne badania granatów występujących akcesorycznie w łupkach cynonośnych, a przede wszystkim zawartych w nich wrostków kasyterytów i ilmenitów, oraz sama strefowość granatów metamorficznych mogą wskazywać na hydrotermalną oraz postmetamorficzną geneze mineralizacji kasyterytowej (Kozłowski i in., 1988; Wiszniewska i in., 1998). Z kolei Cook i Dudek (1994) łączyli powstanie przynajmniej części polimetalicznej (Co-Ni-As-Bi-Ag) mineralizacji siarczkowej w czasie jednej $\mathrm{z}$ faz wysokotemperaturowego metamorfizmu regionalnego. Istnieje również szereg prac przedstawiających osadową premetamorficzną (syngenetyczną) genezę mineralizacji cynowej (m.in. Szłamacha, 1976). Część badaczy (Piestrzyński, Mochnacka, 2003), jak również autorzy niniejszego artykułu wskazują ponadto na bardziej złożoną, metasomatyczno-hydrotermalną genezę, związaną z wieloetapowym rozwojem procesów intruzyjno-metamorficznych cyklu przed- i synwaryscyjskiego (Mikulski i in., 2007).

Występowanie kasyterytu zostało opisane w dwóch asocjacjach mineralnych: pierwsza (łupkowa) - jest wcześniejsza, reprezentowana przez kasyteryt występujący jako wrostki w innych minerałach, oraz druga (kwarcowa) późniejsza, zawiera fragmenty asocjacji łupkowej zaangażowane tektonicznie oraz akcesoryczną mineralizację siarczkową (Berendsen i in., 1987; Michniewicz, Sroga, 1987; Kucha, Mochnacka, 1998). Obie asocjacje zatem współwystępują ze sobą oraz można wyróżnić w nich dwa rodzaje kasyterytu: brązowy i bezbarwny. Brązowy przez część badaczy jest również określany jako kasyteryt gabczasty ze względu na swoje charakterystyczne wykształcenie (Jaskólski, Mochnacka, 1959), natomiast odmiana bezbarwna jest nazywana kasyterytem groniastym (Szałamacha, Szałamacha, 1974). Skupienia kasyterytu brązowego charakteryzują się przeważnie zróżnicowaniem kształtu agregatów - od kulistych do ksenomorficznych oraz niekiedy są również spotykane skupienia warstewkowe (typu woodtin) (Siemiątkowski, 1989). Wielkość skupień tej odmiany kasyterytu waha się w granicach $0,001-0,8 \mathrm{~mm}$. Kasyteryt bezbarwny natomiast cechuje hipautomorfizm kryształów o rozmiarach $\mathrm{w}$ granicach $0,001-0,35 \mathrm{~mm}$. Wyróżnione odmiany kasyterytu występują razem lub osobno. W badanych próbkach zaobserwowano bardzo niewielkie ilości kasyterytu w asocjacji łupkowej (w obrębie lamin chlorytowo-muskowitowych) występujące w skupieniach groniastych o wielkości agregatów poniżej $0,8 \mathrm{~mm}$.

Analizy przenośnym spektrometrem pXRF wykonane na ścianach historycznych wyrobisk wskazały podwyższone zawartości $\mathrm{Cu}, \mathrm{V}, \mathrm{Co}, \mathrm{Zn}, \mathrm{Pb}, \mathrm{W}$ oraz La i Ce. Należy jednak podkreślić różnice rozbieżności wyników uzyskanych in situ za pomocą przenośnego urządzenia pXRF oraz wyników laboratoryjnych analiz WD-XRF, np. średnia zawartość $\mathrm{V}$ jest niemal $4 \times$ wyższa $\mathrm{w}$ analizach przenośnym spektrometrem, podczas gdy średnia zawartość Sn zmierzona laboratoryjnie jest niemal trzykrotnie wyższa od wartości uzyskanej przy pomocy spektrometru przenośnego. Rozbieżności te wynikają zarówno z różnicy czułości detekcji obu urządzeń, jak i formy analizowanego materiału - w przypadku analiz chemicznych mamy do czynienia z uśrednioną próbką, natomiast punktowy pomiar in situ spektrometrem przenośnym przedstawia wyniki zliczeń z określonego pola powierzchni skały niehomogenicznej.

Geochemiczne badania laboratoryjne prób ze sztolni św. Jana i św. Leopolda wykazały wzbogacenie w wiele interesujących pierwiastków rzadkich, takich jak Bi, Hf, In, Pd, Pt, Sc, Sb, W, As, Ag, Cd, Re, Zn, Pb, oraz niektórych REE, których nośnikami mogą być zarówno minerały kruszcowe, jak i skałotwórcze łupków. Ponadto zaobserwowano również nieznacznie podwyższone zawartości innych metali - Zn (śr. 656,08 ppm), Pb (śr. 665,42 ppm), $\mathrm{Cu}$ (śr. 137,92 ppm) i As (śr. 272,38 ppm) oraz Ba (śr. 193,08 ppm). Wyniki zawartości ww. pierwiastków uzyskanych z prób ze sztolni św. Jana i św. Leopolda są zbliżone do wyników z prób pochodzących z innych miejsc pasma łupkowego Starej Kamienicy (Mikulski i in., 2018; Małek, Mikulski, 2019). Różnice jakie należy wskazać to m.in.: zubożenie $\mathrm{w}$ ind (średnia geometryczna dla pasma Starej Kamienicy - 0,41 ppm; Małek, Mikulski, 2019), miedź, arsen i cynk w próbkach ze sztolni oraz niewielkie wzbogacenie w platynę (średnia geometryczna dla pasma Starej Kamienicy - 46 ppb; Małek, Mikulski, 2019).

Obecna w łupkach z historycznych sztolni mineralizacja siarczkowa towarzysząca kasyterytowi została rozpoznana jako nośnik podwyższonych koncentracji niektórych pierwiastków, w tym pierwiastków rzadkich występujących w formie domieszek w minerałach kruszcowych. Należy tu wskazać przede wszystkim domieszki kobaltu (maks. 
$0,137 \%$ wag.) w chalkopirycie, arsenopirycie (maks. 0,210\% wag.), gersdorfficie (maks. 11,219\%) i mimetezycie (maks. 0,294\% wag.), niklu (maks. 0,661\% wag.) w pirycie oraz w arsenopirycie (maks. 0,809\% wag.). W sfalerycie pomiary wykazały podwyższone koncentracje srebra (maks. 0,289\% wag.) i złota (maks. 0,980\% wag.). Uzyskane wyniki zawartości domieszek w minerałach kruszcowych w zasadzie niewiele obiegają od wyników z innych prób pochodzących z łupków pasma Starej Kamienicy (Małek, Mikulski, 2019). Piestrzyński i Mochnacka (2003), badając próbki z Przecznicy i Gierczyna metodą MAR (mikroanalizator Jeol 733), wskazywali dodatkowo na domieszki indu w sfalerytach (maks. 1,39\% wag.) i stanninach (maks. $3,21 \%$ wag.), bizmutu w galenie (maks. 1,11\% wag.) oraz srebra w stanninie (maks. 5,56\% wag.)

Autorzy bardzo serdecznie dziękują Burmistrzowi Miasta i Gminy Mirsk - panu Andrzejowi Jasińskiemu, inspektorowi ds. turystyki - pani Danucie Wołoseckiej, oraz przewodnikowi po Geoparku w Krobicy - panu Piotrowi Telingo za umożliwienie przeprowadzenia badań w sztolniach św. Jana i św. Leopolda w Krobicy. Autorzy kierują również serdeczne podziękowania do pani prof. dr hab. Janiny Wiszniewskiej i pana prof. dr hab. inż. Adama Piestrzyńskiego za wnikliwe recenzje i cenne uwagi oraz do całej Redakcji Przeglądu Geologicznego

\section{LITERATURA}

BARBALACE K. 2019 - Periodic Table of Elements. https://environmentalchemistry.com

BAU M., SCHMIDT K., PACK A., BENDEL V., KRAEMER D. 2018 The European Shale: An improved data set for normalisation of rare earth element and yttrium concentrations in environmental and biological samples from Europe. Appl. Geochem., 90: 122-149.

BERENDSEN P., SPECZIK S., WISZNIEWSKA J. 1987 - Sulphide geochemical studies of the stratiform tin deposits in the Stara Kamienica Chain (SW Poland). Arch. Miner., 42 (2): 31-42.

BOBINSKI W. 1991 - Wrostki kasyterytu w minerałach skałotwórczych. [W:] Mineralizacja Sn i jej pozycja w ewolucji geologicznej pasma kamienieckiego (Góry Izerskie - Sudety Zachodnie). Mat. CXXXI Sesji Nauk. PIG, 4-5.06.1991 r., Wrocław: 23.

COOK N.J., DUDEK K. 1994 - Mineral chemistry and metamorphism of garnet chlorite-mica schist associated with cassiterite-sulphide mineralization from the Kamienica Range, Izera Mountains, S.W. Poland. Chemie der Erde, 54: 1-32

COM 2017 - Komunikat komisji do Parlamentu Europejskiego, Rady, Europejskiego Komitetu Ekonomiczno-Społecznego i Komitetu Regionów w sprawie wykazu surowców krytycznych dla UE 2017. Komisja Europejska, Bruksela, 13.09.2017 r

DZIEKOŃSKI T. 1972 - Wydobywanie i metalurgia kruszców na Dolnym Ślasku od XIII do połowy XX wieku, Wrocław, Ossolineum: 338-360.

JANIK E., GŁADYSZ R., KŁODNICKI A. 1984 - Dokumentacja geologiczna złoża rud cyny „Krobica” w kat. c2. Nar. Arch. Geol. Państw. Inst. Geol., Warszawa.

JASKÓLSKI S., MOCHNACKA K. 1959 - Złoże cyny w Gierczynie w Górach Izerskich na Dolnym Śląsku i próba wyjaśnienia jego genezy. Arch. Miner., 22 (1): 17-106.

KARWOWSKI Ł., WŁODYKA R. 1981 - Stannine in the cassiterite-sulphide deposits of the Izera Mts (Sudetes). Acta Geol. Pol., 31 (1-2) $41-47$.

KOTOWSKI J. 1972 - Stanowisko tektoniczne i geneza skał kwarcowych południowej cześci Pogórza Izerskiego. Pr. Nauk. Inst. Geotech. PWroc., 8, Monografie, 2: 1-115.

KUCHA H., MOCHNACKA K. 1998 - Cassiterite microinclusions and phyllosilicates from tin-bearing schists (Gierczyn, the Western SudetesMts., Poland) and their genetic significance. Miner. Pol., 29 (2): 41-56.

KUCHA H., MOCHNACKA K. 1987 - Preliminary report on bismuth minerals from the Gierczyn tin deposit, Lower Silesia, Poland. Miner. Pol., 17 (1): 55-61.

KOWALSKI W., KARWOWSKI Ł., ŚMIETAŃSKA I., DO VAN PHI., 1978 - Mineralizacja kruszcowa w Kamienickim Pasmie Łupkowym w Górach Izerskich. Pr. Nauk. UŚl. 243, Geologia, 3: 7-90.

KOZŁOWSKI A. WISZNIEWSKA J., METZ P., 1988 - Garnet-bearing parageneses of the tin deposits in the StaraKamienica Chain, Lower Silesia. Fortschr. Miner., B (66): 86

MALON A., TYMIŃSKI M., MIKULSKI S.Z., OSZCZEPALSKI S 2018 - Surowce metaliczne. [W:] Szuflicki M. i in. (red.), Bilan zasobów złóż kopalin w Polsce. Państw. Inst. Geol., Warszawa: 49-63.
MALEK R., MIKULSKI S. 2019 - Geochemiczno-mineralogiczne badania zawartości pierwiastków rzadkich i towarzyszących w obrębie mineralizacji kasyterytowo-siarczkowej w łupkowym paśmie Starej Kamienicy w Sudetach Zachodnich - wyniki wstepne. Prz. Geol., 67 (3): 179-182. McDONOUGH W.F., SUN S.-S. 1995 - Composition of the Earth. Chemical Geol., 120: 223-253.

MICHNIEWICZ M., BOBIŃSKI W., SIEMIATTKOWSKI J. 2006

Mineralizacja cynowa w środkowej części pasma łupkowego Starej Kamienicy (Sudety zachodnie). Pr. Państw. Inst. Geol., 186.

MICHNIEWICZ M., BOBIŃSKI W., SIEMIĄTKOWSKI J. 2002

Monografia złóż rud cyny z łupków łyszczykowych pasma starej kamienicy w Sudetach. Arch. PIG oddz. we Wrocławiu.

MICHNIEWICZ M., SROGA C. 1987 - Dokumentacja geologiczna złoża rud cyny „Krobica Zachód-Czerniawa”. Sprawozdanie geologiczne. Centr. Arch. Geol. Państw. Inst. Geol. Warszawa.

MIKULSKI S.Z., OSZCZEPALSKI S., SADŁOWSKA K., CHMIELEWSKI A., MAŁEK R. 2018 - Występowanie pierwiastków towarzyszacych i krytycznych w wybranych udokumentowanych złożach rud $\mathrm{Zn}-\mathrm{Pb}, \mathrm{Cu}-\mathrm{Ag}$, Fe-Ti-V, Mo-Cu-W, Sn, Au-As i Ni w Polsce. Biul. Państw. Inst. Geol., 472: 21-52.

MIKULSKI S.Z., KOZLOWSKI A., SPECZIK S. 2007 - Fluid inclusion study of gold-bearing quartz-sulphide veins and cassiterite from the Czarnow As deposit ore (SW Poland). [W:] Colin J.A.i in. (red.), Digging deeper. Proceedings of the Ninth Biennial SGA Meeting, Dublin: 805-808. MOCZYDŁOWSKA H., ZAGOŻDŻON P. 2013 - Cyfrowy model trasy podziemnej turystycznej „Kopalnia Św. Jan” w Krobicy. [W:] Mining Sci., 20: $27-38$

MOCHNACKA K., OBERC-DZIEDZIC T., MAYERA W., PIECZKA A. 2015 - Ore mineralizationrelated to geologicalevolution of the Karkonosze-Izera Massif (the Sudetes, Poland) - Towards a model. Ore Geol. Rev., 64: 215-238.

MOCHNACKA K. 1986 - Structures and textures of ores from the Gierczyn tin ore deposits (Sudetes, Poland) and their genetic interpretation. Miner. Pol., 16 (1): 85-96.

NEUMANN U., OLSZEWSKI T. 1991 - Dokumentacja geologiczna złoża rud cyny „Gierczyn” w kat. C2 + C1. Nar. Arch. Geol. Państw. Inst. Geol., Warszawa.

OBERC J. 1958 - Izerska seria suprakrustalna. Prz. Geol., 6 (8-9): 389 OBERC-DZIEDZIC T. 1975 - Enklawy gnejsowe w granicie rumburskim wschodniej części bloku izerskiego. Acta Univ. Wratisl., 247: 165-210. PIESTRZYŃSKI A., MOCHNACKA K. 2003 - Uwagi o mineralizacji siarczkowej towarzyszącej strefom cynonośnym Pasma Kamienieckiego

- Sudety Zachodnie. [W:] Ciężkowski W. i in., Sudety Zachodnie od wendu do czwartorzędu. WIND, Wrocław: 169-182.

PIESTRZYŃSKI A., MOCHNACKA K., MAYER W., KUCHA H. 1990 - Scheelite and ferberite from the tin-bearing schists of the Kamienica Range (the Sudety Mts., SW Poland). Miner. Pol., 21 (1-2): 5-14.

PIESTRZYŃSKI A., MOCHNACKA K., MAYER W., KUCHA H. 1992 - Native gold (electrum), $\mathrm{Fe}-\mathrm{Co}-\mathrm{Ni}$ arsenides and sulphoarsenides in the mica schists from Przecznica, the Kamienica Range, SW Poland. Mineral. Pol., 23 (1): 27-43.

SZAŁAMACHA M., SZAŁAMACHA J. 1974 - Geologiczna i petrograficzna charakterystyka łupków mineralizowanych kasyterytem na przykładzie kamieniołomu w Krobicy. Biul. Państw. Inst. Geol., 279: 59-89.

SZAEAMACHA M. 1976 - On the origin of cassiterite mineralization in the metamorphic schists of the Karkonosze-Góry Izerskie (Mts.) Block, the Sudetes. [W:] Fedak J. (red.), The current metallogenic problems of Central Europe. Wyd. Geol., Warszawa: 343-349.

SZAŁAMACHA M. 1967 - O mineralizacji cynowej we wschodniej części pasma kamienieckiego w Górach Izerskich. Prz. Geol., 15 (6): 281-284.

SIEMIA_TKOWSKI J. 1989 - Tekstury warstewkowe kasyterytów z łupków łyszczykowych okolic Czerniawy Zdroju w Górach Izerskich. Prz. Geol., 37 (9): 430-432.

SIEMIATKOWSKI J. 1991 - Struktury i tekstury kasyterytu w zmineralizowanych łupkach metamorficznych pasma kamienieckiego Gór Izerskich i ich znaczenie genetyczne. Piul. Państw. Inst. Geol., 367: 49-60.

SMULIKOWSKI W. 1972 - Petrograficzne i strukturalne problemy północnej okrywy granitu Karkonoszy. Geol. Sud., 6: 97-188.

TAYLOR S.R. 1964 - Abundance of chemical elements in the continental crust: a new table. Geochim. Cosmochim. Acta, 28: 1273-1285.

WISZNIEWSKA J. 1983 - Problem of Genesis of Tin mineralization of the Izera schists in Kamienickie Range. Arch. Miner., 38 (2).

WISZNIEWSKA J. 1984 - Geneza okruszcowania łupków izerskich pasma kamienieckiego. Arch. Miner., 40 (1): 115-187.

WISZNIEWSKA J., KOZłOWSKI A., METZ P. 1998 - Significance of the composition of garnet to clarify the origin of tin mineralization in the Stara Kamienica schist belt, southwest Poland. Proc. of IX-th Qadrennial Symp. IAGOD Beijing, China, Stuttgart: 463-473.

ZAGOŻDŻON K., ZAGOŻDŻON P. 2012 - Budowa geologiczna górotworu w dostępnych sztolniach rejonu Krobicy-Przecznicy [W:] Zagożdżon P.P., Madziarz M. (red.), Dzieje górnictwa - element europejskiego dziedzictwa kultury. T. 4, Wyd. PWroc., Wrocław: 411-434.

Praca wpłynęła do redakcji 18.07.2019 r.

Akceptowano do druku 8.10.2019 r. 


\section{Charakterystyka mineralogiczno-geochemiczna mineralizacji}

kasyterytowo-siarczkowej w historycznych sztolniach św. Jan i św. Leopold w paśmie lupkowym Starej Kamienicy (Zachodnie Sudety) - patrz str. 914

The geochemical-mineralogical characteristic of cassiterite-sulphide mineralization in the historic Saint John and Saint Leopold shafts in the Stara Kamienica shist belt (Western Sudetes) - see p. 914
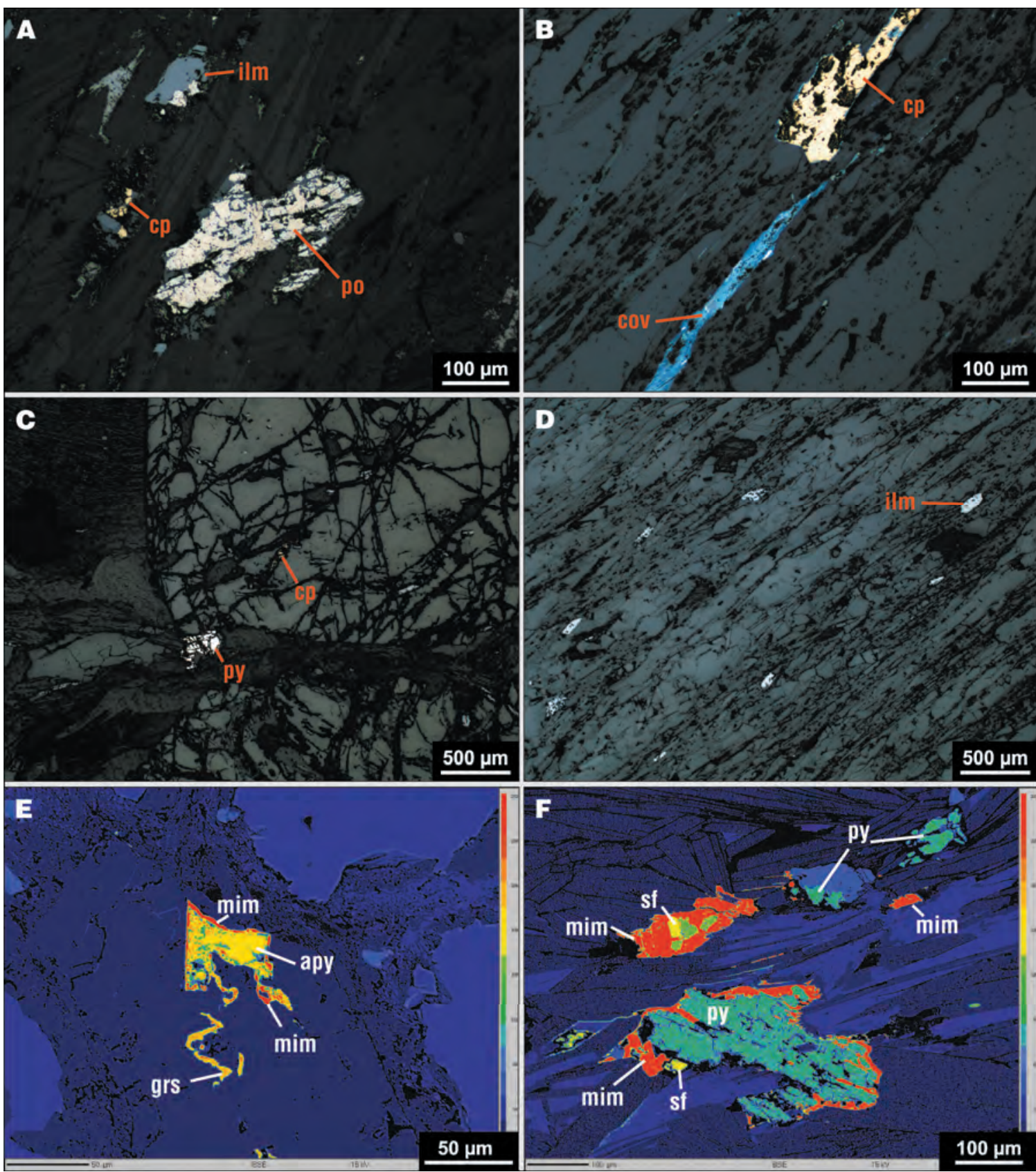

Ryc. 8. A - typowy agregat siarczkowy po-cp-ilm w obrębie laminy chlorytowej, próbka JAN 10, światło odbite, 1N; B - zastępowanie chalkopirytu przez kowelin, próbka LEOPOLD 35, światło odbite, 1N; C - wrostki chalkopirytu w granacie, próbka JAN 44a(45), światło odbite, 1N; D - impregnacja ilmenitowa skały, próbka LEOPOLD 27, światło odbite, 1N; E - agregat arsenopirytu z gersdorfitem oraz obwódka mimetezytowa, próbka JAN 10, obraz BSE, $15 \mathrm{kV}$; F - obwódki mimetezytowe, próbka JAN 10, obraz BSE, 15 kV. Objaśnienia: ilm - ilmenit, cp - chalkopiryt, po - pirotyn, cov - kowellin, apy - arsenopiryt, mim - mimetezyt, grs - gersdorffit, sf - sfaleryt, py - piryt

Fig. 8. A - typical po-cp-ilm sulfide aggregate within a chlorite lamina, JAN 10 sample, reflected- and plane-polarized light; B - covelline replacing chalcopyrite, LEOPOLD 35 sample, reflected- and plane-polarized light; C - chalcopyrite inclusion in garnet, JAN 44a(45) sample, reflected- and plane-polarized light; D - ilmenite impregnation, LEOPOLD 27 sample, reflected- and plane-polarized light; E - gersdorffite-arsenopyrite aggregate with a mimetite rim, JAN 10 sample, BSE, $15 \mathrm{kV} ; \mathbf{F}$ - mimetite rims, JAN 10 sample, BSE, $15 \mathrm{kV}$. Abbreviations: ilm - ilmenite, cp - chalcopyrite, po - pyrrhotite, cov - covellite, apy - arsenopyrite, mim - mimetite, grs - gersdorffite, $\mathrm{sf}$ - sphalerite, py - pyrite 